Vol 7 No. 2,2019

(C2019 Ilmu Komputer Unila Publishing Network all rights reserved

Jurnal Komputasi

\title{
Analisis Kebutuhan Bahan Ajar Geometri Berbantuan Aplikasi Komputer
}

\author{
${ }^{1}$ Fertilia Ikashaum, ${ }^{2}$ Kartika Sari Dewi, ${ }^{3}$ Lena Wahyuni \\ 123 Tadris Matematika, IANI Metro, 35141 \\ *1ikashuma@gmail.com, ${ }^{2}$ kartikawijaya08@gmail,com, ${ }^{3}$ lenawhy69@gmail,com
}

\begin{abstract}
This research aimed to find out the need for modules aided by computer applications in the geometry course at IAIN Metro. This research is a descriptive exploratory study. The method used in the form of a questionnaire which completed with interviews to get more in-depth results. Data obtained from the percentage of the results of the total number of responses for all respondents then analyzed descriptively qualitatively. The conclusion of this study is that it needs to be developed teaching materials in the form of modules aided by computer applications in geometry courses.
\end{abstract}

Keywords: geometry, module

\section{PENDAHULUAN}

Kerangka Kualifikasi Nasional Indonesia (KKNI) menetapkan capaian lulusan perguruan tinggi agar mampu mengaplikasikan bidang keahlian dan memanfaatkan ilmu pengetahuan, teknologi, dan seni (IPTEKS) untuk menyelesaikan permasalahannya serta mampu beradaptasi terhadap situasi yang dihadapi [3]. Paradigma ini berkembang memasuki era revolusi industri 4.0 pada tri darma perguruan tinggi yaitu integrasi keterampilan baru dalam kurikulum tanpa menambah mata kuliah atau SKS [8]. Oleh karena itu, peranan teknologi menjadi penting untuk disisipkan dalam dunia pendidikan sehingga pendidikan dapat menjadi jalan untuk menghadapi problema dalam kehidupan saat ini maupun yang akan datang [1].

Peranan teknologi menyebabkan bidang pekerjaan yang berkaitan dengan komputer, matematika, arsitektur dan teknik akan semakin banyak dibutuhkan. Bidang keahlian ini diproyeksikan sesuai dengan tuntutan pekerjaan yang mengandalkan teknologi digital [5]. Teknologi yang berkembang ini dapat juga diterapkan di dunia pendidikan, salah satunya menggunakan aplikasi komputer untuk mempermudah proses belajar mengajar. Dengan demikian dibutuhkan suatu metode untuk mengaplikasikan kemudahan ini dalam pembelajaran, salah satunya dengan menggunakan media aplikasi [6]. terutama pada matematika yang memiliki kecenderungan mengubah suatu representasi matematis ke bentuk representasi yang lain.

Matematika sendiri menurut James dan James [10]. adalah ilmu tentang logika mengenai bentuk,susunan, besaran, dan konsep-konsep yang berhubungan satu dengan yang lainnya dengan jumlah yang banyak dan terbagi ke dalam tiga bidang, yaitu aljabar, analisis, dan geometri. Salah satu cabang yang selalu dipelajari sejak sekolah dasar hingga perguruan tinggi adalah geometri.

Geometri pada perguruan tinggi mencakup geometri bidang, geometri ruang, dan geometri transformasi.

Dari hasil observasi yang dilakukan terhadap mata kuliah geometri, ditemukan beberapa permasalahan, salah satunya dalam mata kuliah geometri analitik ruang. Ketika mahasiswa menjumpai soal dimensi tiga, mahasiswa diminta untuk mencari panjang garis yang menghubungkan titik tengah dua buah diagonal ruang suatu balok. Jika tidak ada alat peraga atau media pembelajaran, tentu tidak semua mahasiswa mampu memvisualisasikannya [7]. Sedangkan mata kuliah geometri menuntut mahasiswa untuk membayangkan sebuah bangun agar bisa memecahkan soal. Tidak hanya masalah kemampuan memvisualisasikan, namun juga pemahaman mahasiswa akan istilah geometri juga ternyata bermasalah. 
Kendala lain yang ditemukan adalah pemakaian bahan ajar yang digunakan, yaitu perpaduan beberapa buku paket berbentuk modul ajar. Karena menggunakan beberapa sumber referensi, pemakaian simbol dan istilah geometri menjadi tumpang tindih. Selain itu modul yang digunakan belum mampu memfasilitasi semua capaian pembelajaran geometri. Modul tersebut belum memberikan representasi bentuk-bentuk geometri yang diinginkan agar mahasiswa mampu membayangkan secara visual bangun geometri yang dimaksud.

Modul sendiri merupakan salah satu media cetak yang memuat rumusan tujuan yang harus dicapai, materi pelajaran yang harus dikuasai, cara mempelajarinya, tugas-tugas yang harus dikerjakan oleh siswa, sampai pada bahan evaluasi yang harus dikerjakan untuk mengukur keberhasilan siswa mencapai tujuan [9]. Modul ditulis dengan tujuan agar peserta didik dapat belajar secara mandiri tanpa atau dengan bimbingan guru [4].

Kaitannya dengan perkembangan teknologi, saat ini mulai banyak dikembangkan modul berbantuan aplikasi untuk membantu memvisualisasikan objek-objek matematika yang bentuknya abstrak. Terlebih untuk mata kuliah geometri yang memerlukan representasi dalam bentuk-bentuk geometrinya. Untuk itu diperlukan suatu inovasi dalam menyusun modul, yaitu menggunakan aplikasi komputer dalam proses belajar mengajar sehingga objek abstrak geometri dapat dijelaskan secara visual menggunakan berbagai sudut pandang sehingga lebih mudah direpresentasikan oleh mahasiswa.

\section{METODE PENELITIAN}

Penelitian ini merupakan penelitian deskriptif eksploratif. Subjek penelitian adalah mahasiswa tadris matematika angkatan 2017 dan 2018 di Institut Agama Islam Negeri Metro yang telah menempuh mata kuliah geometri analitik bidang, geometri analitik ruang, dan geometri transformasi. Sampel dipilih secara acak sebanyak 20 mahasiswa. Data dikumpulkan dengan menggunakan kuisioner dan lembar wawancara.

Kuisioner analisis kebutuhan modul berbantuan aplikasi komputer berisi pertanyaan sebagai berikut:

${ }^{(1)}$ Apakah menurut anda banyak mata kuliah program studi yang sulit dipahami jika belajar mandiri? (banyak jika lebih dari tiga mata kuliah)

${ }^{(2)}$ Apakah anda memiliki buku teks atau buku pegangan lain untuk setiap mata kuliah yang pernah ditempuh?

(2.a.) Jika ya, apakah dengan buku tersebut anda dipermudah untuk lebih memahami konsep yang akan dipelajari secara mandiri?

(2.b.) Apakah terdapat kesulitan mempelajari bahan tersebut? (misalnya karena kelengkapan materinya, teknik penjelasan, formatnya, dan lain-lain)

${ }^{(3)}$ Apakah anda mencari materi kuliah selain dari yang diberikan oleh dosen untuk membantu anda dalam memahami suatu materi? (misalnya lewat modul atau internet)

${ }^{(4)}$ Apakah dosen anda menggunakan bahan ajar khusus dalam perkuliahan? (misalnya modul, video, alat peraga, dan lain-lain)

(4.a.)Jika ya, apakah anda antusias saat mengikuti perkuliahan?

${ }^{(5)}$ Apakah anda merasa kesulitan dengan bahan ajar yang selama ini dipakai dosen anda?

${ }^{(6)}$ Apakah anda pernah diajak oleh dosen anda untuk praktikum dalam mata kuliah yang memerlukan penguasaan keterampilan penggunaan alat bantu matematika?

${ }^{(7)}$ Apakah anda membutuhkan bahan ajar alternatif yang dapat digunakan untuk mempelajari konsep matematika secara lebih mudah dan menarik?

${ }^{(8)}$ Sebagai calon guru, apakah anda merasa perlu menguasai media pembelajaran yang menarik?

${ }^{(9)}$ Apakah menurut anda pembelajaran lebih menarik jika menggunakan media pembelajaran berbantuan IT?

${ }^{(10)}$ Apakah anda sering menggunakan aplikasi komputer yang berhubungan dengan konsep geometri? (misalnya Wingeom, Geogebra, Geometers Sketchpad, Cabri, dan lain-lain)

${ }^{(11)}$ Apakah anda setuju apabila perlu dikembangkan bahan ajar seperti modul berbantuan aplikasi komputer untuk membelajarkan konsep-konsep geometri sehingga lebih menarik dan mudah dipahami? 
${ }^{(12)}$ Apakah anda ingin mengembangkan kompetensi diri menyesuaikan dengan perkembangan media berbantuan IT?

Permasalahan yang akan dibahas dalam penelitian ini adalah untuk mengetahui seberapa besar kebutuhan pemakaian modul berbantuan aplikasi komputer dengan cara pengisian kuisioner dan wawancara subjek penelitian. Adapun lembar wawancara berisi pertanyaan yang sama namun untuk mendapatkan informasi yang lebih lengkap dari hasil kuisioner tiap mahasiswa.

\section{HASIL DAN PEMBAHASAN}

Analisis kebutuhan modul berbantuan aplikasi komputer dilakukan menggunakan kuisioner yang berisi tentang materi mata kuliah geometri yang sulit dipahami, bahan ajar yang dipakai mahasiswa, serta identifikasi modul berbantuan komputer yang disukai oleh mahasiswa.

Tabel 1. Persentase Kuisioner Mahasiswa

\begin{tabular}{ccc}
\hline Item & Ya & Tidak \\
\hline 1 & $97 \%$ & $3 \%$ \\
2 & $17 \%$ & $83 \%$ \\
$2 \mathrm{a}$ & $52 \%$ & $48 \%$ \\
$2 \mathrm{~b}$ & $69 \%$ & $31 \%$ \\
3 & $100 \%$ & $0 \%$ \\
4 & $100 \%$ & $0 \%$ \\
$4 \mathrm{a}$ & $90 \%$ & $10 \%$ \\
5 & $83 \%$ & $17 \%$ \\
6 & $28 \%$ & $72 \%$ \\
7 & $100 \%$ & $0 \%$ \\
8 & $100 \%$ & $0 \%$ \\
9 & $97 \%$ & $3 \%$ \\
10 & $10 \%$ & $90 \%$ \\
11 & $100 \%$ & $0 \%$ \\
12 & $100 \%$ & $0 \%$ \\
\hline
\end{tabular}

Uraian materi yang dianggap sulit pada mata kuliah geometri diambil dari hasil kuisioner responden dengan persentase sebesar $97 \%$ menjawab sulit. Selanjutnya berdasarkan analisis wawancara diketahui bahwa materi tersebut berkaitan dengan soal-soal yang memerlukan interpretasi bangun geometri secara abstrak. Misalnya pada geometri analitik ruang, mahasiswa merasa sulit menggambarkan proyeksi titik atau garis yang terletak di oktan enam atau delapan.

Pada geometri analitik bidang, diketahui bahwa pengerjaan soal berbentuk persaman umum jika tidak disertai dengan visualisasi bangun geometri akan sulit diterjemahkan oleh mahasiswa. Hal yang sama juga terjadi pada geometri transformasi, soal berbentuk kalimat sulit direpresentasikan jika tidak dibantu dengan visualisasi bangun geometri.

Analisis bahan ajar yang digunakan di mata kuliah geometri dibahas pada item dua sampai tujuh. Sebanyak $17 \%$ responden menjawab bahwa mereka memiliki buku pegangan atau buku referensi untuk setiap mata kuliah geometri yang pernah ditempuh. Baik itu disediakan oleh dosen atau mereka menggunakan buku referensi sendiri. Buku yang digunakan membuat mahasiswa lebih memahami konsep geometri jika belajar secara mandiri, namun tetap terkendala oleh teknik penjelasan, kelengkapan materi, maupun kesalahan pengetikan dari buku tersebut. Selanjutnya, sebanyak 83\% responden yang menjawab bahwa mereka tidak puas dengan bahan ajar yang digunakan mencari sumber materi lain dari internet (melalui mesin pencari maupun video pembelajaran). Akan tetapi, kesulitan lain 
yang dihadapi adalah pemakaian simbol dan istilah geometri yang berbeda dengan yang digunakan dosen jika menggunakan materi dari internet.

Tidak setiap mata kuliah geometri menggunakan bahan ajar khusus yang dipakai oleh dosen, dibuktikan dari $100 \%$ jawaban responden yang menyatakan setuju. Dari hasil wawancara diketahui bahwa bahan ajar khusus yang digunakan adalah modul untuk mata kuliah geometri analitik bidang dan geometri transformasi. Modul pada geometri analitik bidang menggunakan modul buatan dosen sendiri sedangkan modul geometri transformasi menggunakan modul dari penerbit lain dengan penyesuaian. Kemudian sebanyak $90 \%$ responden merasa lebih antusias mengikuti perkuliahan jika menggunakan bahan ajar dari dosen.

Pada penyataan kuisioner berikutnya, sebanyak $83 \%$ responden menjawab bahwa mereka merasa kesulitan memahami bahan ajar yang dipakai dosen selama ini karena bahan ajar yang digunakan belum dapat memfasilitasi kebutuhan representasi bangun geometri. Selain itu juga masih terdapat beberapa kesalahan cetak dalam penulisannya.

Dalam menggunakan aplikasi pendukung pembelajaran geometri, sebanyak $28 \%$ responden menjawab bahwa mereka ikut aktif menggunakan aplikasi tersebut sehingga memiliki keterampilan untuk menggunakannya juga. Terutama pada mata kuliah geometri analitik bidang, soal ujian yang digunakan merupakan representasi dari bidang geometri ke bentuk persamaan umum.

Sebagai calon guru, keseluruhan responden setuju jika mereka harus menguasai media pembelajaran yang menarik termasuk menguasai aplikasi komputer yang mendukung pembelajaran geometri. Namun terdapat 3\% responden yang tidak setuju jika seluruh materi geometri menggunakan media pembelajaran berbantuan IT karena terbatasnya komputer yang dimiliki secara pribadi oleh mahasiswa, selain itutidak semua mahasiswa mahir dalam mengoperasikan aplikasi yang ada.

Selanjutnya, aplikasi yang pernah mereka gunakan selama pembelajaran geometri adalah geogebra dan cabri. Geogebra digunakan dosen untuk memvisualisasikan bangun geometri pada mata kuliah geometri analitik bidang dan geometri transformasi. Cabri hanya digunakan beberapa mahasiswa untuk mengeksplorasi bangun datar sebagai salah satu tugas akhir mata kuliah yang diwajibkan.

Apabila dikembangkan bahan ajar seperti modul berbantuan aplikasi komputer, seluruh responden setuju agar materi geometri disajikan lebih menarik dan semakin mudah dipahami. Responden juga setuju jika harus menyesuaikan kompetensi diri dengan perkembangan media saat ini yang berbantuan IT.

Tantangan pembelajaran berbantuan teknologi informasi di era revolusi industri salah satunya adalah dengan membuat bahan ajar yang berbantuan aplikasi [11]. Bahan ajar yang dapat dibuat untuk pembelajaran mandiri mencakup materi dan latihan soal adalah modul [4]. Berdasarkan beberapa hasil penelitian yang pernah dilakukan, antara lain [2]. diketahui bahwa pengembangan modul diperlukan bagi materi-materi yang memerlukan representasi lebih lanjut. Modul ini diharapkan dapat menjadi solusi untuk memperbaiki permasalahan yang ditemukan pembelajaran geometri.

\section{KESIMPULAN}

Dari hasil pembahasan diketahui $83 \%$ mahasiswa merasa kesulitan dengan bahan ajar yang selama ini dipakai dosen. Oleh karena itu 100\% mahasiswa merasa setuju bila dikembangkan bahan ajar khusus berbentuk modul yang memfasilitasi visualisasi bangun geometri. Oleh karena itu, diperlukan pengembangan bahan ajar berbantuan aplikasi yang sesuai untuk meningkatkan pembelajaran geometri yang berlaku. Bahan ajar yang dikembangkan hendaknya sesuai dengan kebutuhan mahasiswa akan modul berbantuan aplikasi komputer.

\section{DAFTAR PUSTAKA}

[1] Al-Tabany, T. I. B. (2014). Mendesain Model Pembelajaran Inovatif, Progresif, dan Kontekstual (T. Trianto, Ed.). Jakarta: Prenada Media Group.

[2] Asmi, A. R., Surbakti, A. D., \& Hudaidah. (2018). Pengembangan E-Modul Berbasis Flip Book 
Maker Materi Pendidikan Karakter untuk Pembelajaran Mata Kuliah Pancasila MPK Universitas Sriwijaya. Jurnal Pendidikan Ilmu Sosial, 27(1), 1-10.

[3] Indonesia, R. Perpres No. 8 Tahun 2012 tentang KKNI. , Pub. L. No. 8 Tahun 2012, 1 (2012).

[4] Majid, A. (2005). Perencanaan Pembelajaran: Mengembangkan Standar Kompetensi Guru. Bandung: Remaja Rosdakarya.

[5] Murtini, S., \& Sutedjo, A. (2018). Era Revolusi Industri 4.0: Dilematis Bagi Alumni Universitas Negeri Surabaya. Prosiding Seminar Nasional UNESA: Pendidikan Indonesia Menyongsong Revolusi Industri 4.0, 39-47.

[6] Nur, I. L., Harahap, E., Badruzzaman, F. H., \& Darmawan, D. (2017). Pembelajaran Matematika Geometri Secara Realistis Dengan GeoGebra. Jurnal Teori Dan Terapan Matematika Universitas Islam Bandung, 16(2), 1-6.

[7] Pratiwi, M., \& Septia, T. (2016). Efektivitas Modul Aplikasi Komputer dengan Program Wingeom Pada Materi Geometri. Lemma: Letters of Mathematics Education, III(1), 97-107.

[8] Ristekdikti, K. (2018). Mempersiapkan SDM Indonesia Ke-7 Dunia Ke-4 Dunia.

[9] Sanjaya, W. (2013). Penelitian Pendidikan: Jenis, metode, dan Prosedur (1st ed.). Jakarta: Prenada Media Group.

[10] Suherman. (2007). Strategi Pembelajaran Matematika Kontemporer. Bandung: JICA - UPI.

[11]Syamsuar, \& Reflianto. (2019). Pendidikan dan Tantangan Pembelajaran Berbasis Teknologi Informasi di Era Revolusi Industri 4.0. E-Tech : Jurnal Ilmiah Teknologi Pendidikan, 6(2), 1-13. Retrieved from http://ejournal.unp.ac.id/index.php/e-tech/article/view/101343/100535 